\title{
AND NOW FOR SOMETHING COMPLETELY DIFFERENT ... ONCE AGAIN THE SAME BOOK BY DOSTOEVSKY: A (CON)TEXTUAL ANALYSIS OF EARLY AND RECENT DOSTOEVSKY RETRANSLATIONS INTO DUTCH
}

\author{
Pieter Boulogne 1 \\ -Katholieke Universiteit Leuven, Belgium
}

\begin{abstract}
During the last 10 to 15 years, the Dutch-language book market has witnessed an increase in the number of Dostoevsky retranslations. Whereas some observers explain this development by referring to the ageing of previous translations, the translators themselves tend to justify their translations by calling them "better translations". By offering a comparative contextual and textual analysis of early and recent Dostoevsky retranslations into Dutch, this article tries to explain the phenomena of retranslation in general and of recent Dostoevsky retranslation into Dutch in particular. It does so by going beyond the popular assumptions, which show close ties to the Retranslation Hypothesis. On the basis of a historical analysis, which shows that the first Dostoevsky retranslations into Dutch were more oriented towards acceptability than the first translations, it is argued that the concept of norms, as conceived by Gideon Toury, remains a better tool than the Retranslation Hypothesis to interpret and to explain the phenomenon of the Dostoevsky retranslations into Dutch. However, because of translators' possibilities to go against the norms, which is illustrated through the work of contemporary Dutch translator Hans Boland, norms too fail to provide us with a full explanation.
\end{abstract}

Keywords: Retranslation; Retranslation Hypothesis; Norms; Dostoevsky 


\title{
E AGORA, ALGO TOTALMENTE NOVO... O MESMO LIVRO DE DOSTOIEVSKI: UMA ANÁLISE (CON) TEXTUAL DAS PRIMEIRAS E DAS MAIS RECENTES RETRADUÇÕES DE DOSTOIEVSKI PARA O HOLANDÊS
}

\begin{abstract}
Resumo: Durante os últimos dez ou quinze anos, o mercado de livros em holandês viu um aumento no número de retraduções de Dostoievski. Enquanto alguns explicam esse desenvolvimento com base na caducidade das traduções anteriores, os próprios tradutores tendem a justificar suas traduções dizendo que são "melhores". Oferecendo uma análise comparativa contextual e textual das primeiras e das mais recentes retraduções de Dostoievski para o holandês, o presente artigo busca explicar o fenômeno da retradução em geral e o da retradução de Dostoievski em particular. Isso é feito indo-se além de pressupostos populares, que mostram estreito parentesco com a hipótese da retradução. Com base em uma análise histórica, que mostra que as primeiras retraduções de Dostoievski para o holandês estavam mais orientadas em direção à aceitabilidade que as primeiras traduções, argumenta-se que o conceito de normas, tal como concebido por Gideon Toury, mostra-se uma ferramenta melhor que a hipótese da retradução para se interpretar e explicar o fenômeno das retraduções de Dostoievksi para o holandês. Entretanto, devido à possibilidade de os tradutores irem contra a norma, que é ilustrada pelo trabalho do tradutor holandês contemporâneo Hans Boland, também as normas ficam aquém de prover um explicação completa.
\end{abstract}

Palavras-chave: Dostoievski; Normas; Hipótese da retradução; Tradução para o holandês

\section{Two popular assumptions about the motives behind the recent tsunami of Dostoevsky retranslations into Dutch}

Just over a decade ago, Otto Boele, when commenting on the new translations of Anton Chekhov's complete works, Fyodor Dostoevsky's Brothers Karamazov and a revised translation of Mikhail Sholokhov's The Still Don, noted "a wave" of retranslations from Russian into Dutch. If we adhere to Boele's nautical metaphor, it is safe to say that this wave has now evolved into a tsunami, which has flooded and continues to flood the Dutch- 
language book market with retranslations of virtually all 19thcentury Russian writers with canonical status (writers of the Soviet era - not to mention the post-Soviet era - are notably less featured, although, for instance, in 2013 the complete works by Isaac Babel were retranslated). During the last decade, a dazzling number of pages originally written by Alexander Pushkin, Nikolay Gogol, Lev Tolstoy and particularly Dostoevsky, have been re-voiced in Dutch, very much in line with the suggestion formulated by Isabelle Collombat (1) that the beginning of the 21 st century may be identified as the Age of Retranslation.

As Eric Metz observes, the Russian retranslation boom is largely, but not exclusively, the result of hard work carried out by one specific publishing house: Van Oorschot. The fact of the matter is that Van Oorschot has engaged in renewing, rather than expanding, its prestigious book series 'De Russische Bibliotheek' (The Russian Library), which contains approximately 40 hardcover volumes. For a decade or so, it is Dostoevsky who has been at the centre of attention: virtually all of his minor and major narrative works, including Poor Folks and The Idiot, have been retranslated by various translators and for various occasions. This is remarkable for two reasons. First, as the bibliographies of Russian literature in Dutch translation drawn up by Emmanuel Waegemans (1991, 158179; 2016, 227-229) show, Dutch and Flemish readers were already able to choose between various Dutch retranslations of Dostoevsky and the like, sometimes relatively recent ones, available at the time. Second, at its foundation in 1953, the proclaimed aim of the book series in question was to promote classical Russian writers who were locally still unknown. Although it depends on the definition of 'classical,' it can be argued that today this pioneering goal has not yet been fully achieved. Publishing houses other than Van Oorschot have also not refrained from turning to 'the usual suspects' of the Russian canon. To give just a few examples: in 1999, on the occasion of the jubilee of Pushkin's birth, publishing house Papieren Tijger announced the translation of the complete works by Pushkin (most of whose works had been translated before), which was actually 
completed 17 years later; in 2008, a retranslation of Dostoevsky's Devils (better known in English as The Possessed) was published by Atheneum-Polak \& Van Gennep; and more recently, in the late winter of 2017, the same publishing house printed a retranslation of Tolstoy's Anna Karenina. All these retranslations are the work of one highly productive translator: Hans Boland.

The recent boom in retranslations of Dostoevsky's works and the like has not gone unnoticed in the Low Countries. It has brought the translators involved, in particular Hans Boland and Van Oorschot's translator Arthur Langeveld, high degrees of visibility - so much so that the assumptions made by Lawrence Venuti about the translators' invisibility can essentially be challenged. Using special advertisements and brochures, the publishing houses Van Oorschot and Papieren Tijger actively use their retranslations as tools for self-promotion - quite in line with the observation by Vanderschelden that "publishers often use new translations as a positive marketing devise" (7). Their retranslation policy has undeniably strengthened their own capital, as well as the translators' capital - if not financially, then at least symbolically. The retranslation of Dostoevsky's Brothers Karamazov by Arthur Langeveld in 2005 sold over 4,000 copies in only six months' time (Boele 2). One year later, the translator was awarded the Nijhoffvertaalprijs, the most prestigious and most profitable translation award in the Netherlands (prize money: €35,000). In turn, Boland was offered the Medal of Pushkin in 2014, Russia's prestigious state decoration for cultural achievements. Referring to his esteem for the Russian poet and to his contempt for the Russian president, the Dutch translator respectfully refused the medal (Heijne). However, one year later, he too was awarded the Nijhoffvertaalprijs for his (re)translations from Russian into Dutch.

The attention that the readership has been paying to the awardwinning (re)translators is also the result of the (re)translators' willingness, or even eagerness, to step out of the shadow, both within and outside of the borders of the books that they have translated. In a variety of lectures, seminars, interviews, paratexts 
(e.g., endnotes, epilogues) and separate publications (e.g., articles, book publications dealing with the translated works), both Langeveld and Boland have publicly spoken about their general translation strategies and at times extremely specific translation choices. An extreme illustration of the "apologetic and polemic tendencies" that Eric Metz discovered in the recent retranslations from Russian into Dutch has recently been provided by Boland. On the occasion of his retranslation of Tolstoy's Anna Karenina, Boland wrote articles and essays about his sporadically normbreaking translation choices (an exercise that he had undertaken previously, while translating Dostoevsky's Devils). In these epitexts, Boland $(2016,23)$ explains, for instance, that he courageously improved Tolstoy's "abominable writing style." The Dutch professor emeritus of Russian literature Willem G. Weststeijn (2017) reacted with a substantiated opinion piece, accusing the translator of stylistic unfaithfulness. The discussion was concluded with a rarely-seen shouting match, in which Boland (2017) labelled Weststeijn's reaction as "petty pedantry, as always giving [him] a vague feeling of nausea" (my translation).

The reason behind the creation of paratexts and epitexts by the Dutch retranslators from Russian seems to arise from the need to justify to the readership the raison d'etre of the retranslations. The reasons behind retranslations, as explained to the readership, is twofold. The first reason is that literary translations simply have limited shelf life, which is actually more of an observation than an explanation. According to Maarten Steenmeijer, who commented on a Dutch retranslation of Gabriel García Márquez's One Hundred Years of Solitude, it is generally accepted that "a translated novel lasts about thirty to forty years" (par. 1). The underlying idea is that readers' readiness to overcome barriers of time applies to a lesser extent to translations than to original works. This thought is well known in Translation Studies as "the issue of ageing," mentioned by Berman (1) in his seminal article in the special volume of Palimpsestes as a possible motive for retranslation. Recently, Piet Van Poucke investigated how scholarly literature on 
retranslations deals with ageing as a motive for retranslation. He concludes that the "assumption that every generation deserves its own Dostoevsky [...] is taken for granted by non-academic critics of literary (re)translations" (93), but that Translation Studies scholars have not yet found hard empirical evidence for such assumptions. Moreover, the ageing of a translation can relate to fundamentally different aspects of a translation: not only linguistic and idiomatic aspects, but also translational and cultural aspects. Because of Dostoevsky's ample use of colloquial speech, the Russian author seems especially vulnerable to ageing with regard to linguistic and idiomatic aspects.

With regard to the "translational aspects" of the ageing of a given translation, there is a fine line with the second popular answer given to explain the phenomenon of retranslation: "to offer a 'better' translation," which, as Elżbieta Skibińska notices, generally means "a more adequate translation" (237). ${ }^{1}$ This idea was also central to Berman's Retranslation Hypothesis, according to which retranslations tend to be more source-text-oriented than previous translations, for the simple reason that translation is a process of improvement from one retranslation to the next, coming closer and closer to the source text (Paloposki \& Koskinen). Placing retranslation within a perspective "with a corresponding specific justification for retranslation, on historical, interpretative and reception-oriented grounds," Berman believes that "a great translator," when benefiting from "the minimum distance making the translating process possible," can make "a great translation" - which in his understanding is a translation that is marked by " 'abundance,' instead of the traditional notion of loss" (Vanderschelden 11).

1 The adjective 'adequate' is used here as the non-judgmental term coined by the Israeli translation scholar Itamar Even-Zohar to characterize a "translation which realizes in the target language the textual relationships of a source text with no breach of its own [basic] linguistic system" (translation by Toury, 56). As Toury proposes, throughout this article the opposition between 'adequacy' and 'acceptabililty' is retained "as a basic coordinate system for the formulation of explanatory hypotheses” (60). 
Although the two popular answers as to why retranslations exist - the ageing of the translation and the wish to provide a better translation (whatever 'better' may be) - are not mutually exclusive, both Langeveld and Boland prefer to embrace the 'better translation' answer rather than the 'ageing translation' answer. They have more or less explicitly highlighted that the preexisting Dostoevsky translations left much room for improvement with regard to the dilemma of adequacy/acceptability. In a recent interview, Langeveld explained why this is the case by referring to an improvement of the translators' working conditions:

At the time [when the publishing house Van Oorschot was founded], the internet did not yet exist, dictionaries were hardly available and, in the Netherlands, there were only a couple of Russians whom the translators could ask for help. Moreover, translators' wages were disgracefully low and everything had to be delivered with very short turnaround times. (quoted by Abrahams, my translation from Dutch).

It is striking that when the translators themselves explain what had to be improved, they focus on Dostoevsky's style, which today is generally known to have been praised as 'polyphonic' by Mikhail Bakhtin. In his epilogue to his retranslation of The Brothers Karamazov, Langeveld explained that he "felt obliged to render Dostoevsky's linguistic variegation as much as possible into Dutch, not aiming at 'beauty' in the first place, let alone 'fluently readable Dutch'” (962). In turn, in his essay on Devils, Hans Boland (2008, 84) provides ample examples of translation choices that, according to himself, "render the narrator's chatting style as accurately as Dostoevsky himself."

The translators' claims seem unsatisfactory to explain the reason for the existence of a seemingly vicious circle of Dutch Dostoevsky retranslations. Among other Dutch Slavists, Eric Metz has suggested that Boland's retranslations from Russian, containing 
some anachronistic vocabulary, are even more target-text-oriented than previous translations of the same works. A specific microtextual example from Boland's translation of Devils, highlighted and criticized by Willem G. Weststeijn (2009), is the use of the English phrase "so what?" to render the words of a Russian character in Dutch. Dostoevsky had an intense dislike of English and native speakers of Dutch in the 19th century did not intersperse their speech with English words so it seems somewhat unusual that the English phrase "so what?" was chosen.

\section{The early Dostoevsky retranslations into Dutch}

\subsection{Context and selection of source texts for retranslation}

A historical analysis can provide an understanding of the motivations for the present Dostoevsky retranslation boom that goes beyond any popular answers. More specifically, drawing on a broader study on the early Dutch reception of Dostoevsky (Boulogne 2011), I propose a textual and contextual analysis of the first wave of Dostoevsky retranslations into Dutch. These retranslations were published in the first period after the discovery of Dostoevsky's work in the Netherlands and Flanders, beginning in the mid-1880s and ending with the outbreak of the First World War. The analysis of the circumstances in which the first Dostoevsky retranslations appeared and their shifts from the source texts and from preceding translations can serve to corroborate or to reject the above-formulated popular assumptions about the most recent Dostoevsky retranslations. This historical analysis is based on the conviction that the phenomenon of retranslation should ideally be studied within the specific literary polysystem in which it occurs. However, it should be stressed that retranslating Dostoevsky is not a uniquely Dutch literary phenomenon, but an international one: according to the Unesco Index Translationum (Unesco), Dostoevsky is the most translated Russian writer after 
Vladimir Lenin. By extension, it is highly likely that Dostoevsky is also among the most retranslated Russian writers.

Dostoevsky was discovered in the Netherlands and in Flanders in the mid-1880s. At the time, the Dutch literary polysystem was manifestly subordinated to the French and German literary polysystems. The discovery of Dostoevsky was a direct result of the Russian vogue that held both the French and the German readerships in its grasp. In their essays on Dostoevsky, the Dutch critics paid lip service to the French leading critic Eugène-Melchior de Vogüé, who, in his internationally read articles in Revue des deux mondes and bestseller Le roman russe, had promoted the Russian writer as an antidote against amoral French naturalism à la Zola. However, although Dostoevsky had created a commercially exploitable hype in Paris, which had evoked chauvinist counterattacks against both himself and Vogüe at the turn of the century, the interest of Dutch and Flemish readers in the Russian writer was notably less strong: between 1886 and 1914, only 13 Dutch Dostoevsky book translations were produced, a number that did not include reprints (Boulogne 2011, 402). ${ }^{2}$

Strikingly, some works that today are considered among Dostoevsky's masterpieces, such as The Brothers Karamazov, The Idiot, The Adolescent and Devils, were for many decades not selected for translation into Dutch. In contrast, Dostoevsky's novel The Humiliated and Insulted, today generally considered one of his weakest creations, was retranslated under the title Arme Nelly [Poor Nelly] (Dostojewsky 1891) only five years after Dostoevsky

${ }^{2}$ This is the chronological list of Dutch book translations of Dostoevsky's works, all published before 1914: Schuld en boete [Crime and Penalty] (1885), De misleide [The misled one] (1886), Arme menschen [Poor People] (1887), De kerstboom [The Christmas Tree] (1887), De onderaardsche geest [The Underground Ghost] (1888), De speler [The Gambler] (1890), Arme Nelly [Poor Nelly] (1891), Uit Siberië [From Siberia] (1891), Een misdaad. Wroeging [Crime. Remorse.] (1895). Uit het doodenhuis [From the dead house] (1906), Witte nachten [White nights] (1906), De echtgenoot [The Husband] (1907) and De gebroeders Karamazow [The Brothers Karamazov] (1913). Of these Dutch translations, one could not be found physically, namely De kerstboom [The Christmas Tree] (1887). The other twelve translations together form the target text corpus. 
was discovered in the Netherlands and in Flanders. The corpus of Dutch Dostoevsky translations contains two more retranslations: Uit het doodenhuis [From the dead house] (Dostojewski 1906), a retranslation of Notes from the House of Dead, was printed 15 years after the preceding translation of the same source text. And in 1895, a decade after the first Dutch translation of Crime and Punishment, this novel was retranslated into Dutch in two volumes, Een misdaad/Wroeging [A crime/Remorse]. The Dutch publishers' focus on these specific works is not surprising. All three texts played an important role in the popularization of Dostoevsky in France. The corresponding French texts Humiliés et offensés (Dostoïevsky 1884) and Le crime et le châtiment (Dostoïevsky 1884) were the first Dostoevsky book translations made available to French readers. In turn, Souvenirs de la Maison des morts (Dostoïevsky 1886) was one of the favourite Dostoevsky books of leading critic Vogüé. In Germany too, Crime and Punishment and Notes from the House of Dead were at the very centre of the Dostoevsky mania at the time.

Three of the 13 Dutch target texts are retranslations. These were all published within 15 years or less of the preceding Dutch translations of the corresponding source texts. This timespan was too short for any linguistic norms to have changed meaningfully. Furthermore, the corpus of iate texts - before the First World War indirect translation from French and/or German was a common practice in the Dutch literary polysystem (Boulogne 2015 and 2013) - also contains four retranslations (of a total of 14 texts). ${ }^{3}$

\footnotetext{
${ }^{3}$ The corpus of intermediate text consists of the following German and French translations: Raskolnikow (1882), Erniedrigte und Beleidigte (1885), Aus dem todten Hause (1886), Arme Leute (1887), Der Hahnrei (1888), Der Spieler (1890), Erniedrigte und Beleidigte (1890), Aus dem todten Hause (1890), Les humiliés et offensés (1884), Le crime et le châtiment (1884), L'esprit souterrain (1886), Souvenirs de la maison des morts (1886), Les frères Karamazov (1888) and Les frères Karamazov (1906). Of these 14 translations, the following four are retranslations: the German translations Erniedrigte und Beleidigte [Humiliated and Insulted] (1890), Aus dem todten Hause [From the dead house] (1886), Aus dem todten Hause [From the dead house] (1890) and the French translation Les frères Karamazov [The brothers Karamazov] (1906).
} 
Thus, it is safe to say that retranslation played a vital role in the early Dutch reception of Dostoevsky's literary works.

\subsection{Arme Nelly [Poor Nelly], or the first Dostoevsky retranslation into Dutch}

Before we take a closer look at the specific nature of the first Dostoevsky retranslation into Dutch, let us briefly sketch the plot and reception of the corresponding source text. The Humiliated and Insulted consists of two storylines that come together at the end. The first storyline is sentimental and romantic. The narrator is in love with Natasha, the daughter of an impoverished nobleman. Natasha flees her parental house together with her young lover, Alyosha. Alyosha's father is the rich and evil Valkovsky, who eventually manipulates his son into marrying a girl of higher standing. The second storyline, more a roman feuilleton, centres on Nelly, a poor, mysterious young girl, who - after the death of her mother - falls prey to an evil procuress. The narrator manages to set Nelly free and bring her to Natasha's parents. After hearing Nelly's life story, in which this character turns out to be Valkovsky's bastard daughter, they forgive their own daughter Natasha. Following these developments, Natasha and the narrator die. When Dostoevsky's novel was originally published in 1861, it received little praise from the Russian critics, who did not notice Dostoevsky's idea that psychological suffering can be a moral choice. Nevertheless, it was a success, privileging a sentimental-humanistic interpretation (Frank 117).

Beyond Russia, the early popular reception of The Humiliated and Insulted differed from its early critical reception. The novel received predominantly negative attention from the leading German and French critics who were responsible for the early popularization of Dostoevsky. The German and French critics Eugen Zabel and Vogüé, following the tone set by Alexander von Reinholdt, both criticized the novel, stating that its composition was too long and confusing, and the depiction of the aristocracy 
unconvincing. According to Vogüé, the weak characterizations of Alyosha and his evil father Valkovsky were a source of irritation. However, the critics agreed that the novel had one positive note to it: the character Nelly. Vogüé called her "la délicieuse et navrante petite fille" [the delicious and heartbreaking little girl] (1885, 336). The tough criticism levelled at The Humiliated and Insulted by the German and French critics sharply contrasted with its success among non-professional readers in Western Europe. The popular French and German translations Les humiliés et offensés (Dostoïevsky 1884) and Erniedrigte und Beleidigte [Humiliated and Insulted] (Dostojewski 1885) were promptly followed by an anonymous Dutch translation based upon them: De misleide [The misled one] (Dostojewski 1886). As Figure 1 shows, Dostoevsky's first Dutch retranslation, Arme Nelly [Poor Nelly] (Dostojewsky 1891), appeared only five years later and was based on another German intermediate text, which immediately preceded it and was also entitled Erniedrigte und Beleidigte (Dostojewski 1890).

Obviously, the very fact that indirect translation was systematically chosen does not testify to a concern about the translational norm of adequacy. In comparison to the corresponding German and French intermediate texts and the Russian source text, the paratexts and epitexts that were available to study the target texts De misleide and Arme Nelly, along with the macrostructural and microtextual features of the named target texts, point in the very same direction.

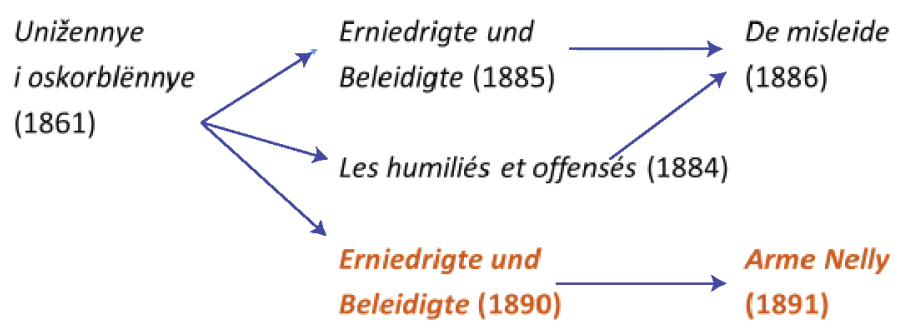

Figure 1: The first Dutch retranslation of The Humiliated and Insulted 
Indications that acceptability was a dominant translation norm can be found on the title pages of both translations (see Figure 2). The title page of De misleide does not mention the translator, the year of publication, or the first name of the source text's author. In so doing, it shows little concern about its own translational status. In turn, the title page of Arme Nelly reads "naar het Russisch," literally meaning "towards the Russian," which might be a hint at its macrostructural shifts (omissions and manipulations of segmentation). Moreover, the respective titles do not point towards adequacy: whereas the Russian title, literally meaning "the humiliated and insulted ones," uses a plural form - which is logical since the novel is about not one but two humiliated girls - the titles of the target texts appear in singular forms, suggesting one main character instead of two. In addition, the denotative meanings of the target-text titles are quite different from the meaning of the source-text title: $D e$ misleide and Arme Nelly mean "The misled one" and "Poor Nelly" respectively. These meanings suggest more passive characters than the title "the humiliated and insulted ones," which presupposes some kind of moral act (indignation) from the victims. What is also interesting about the title Arme Nelly, which showcases Nelly as the one and only main character, is its metaliterary connotation, which is lacking in the source text: the proper name of a young female character in a title brings to mind associations with edifying sentimental novels - often written for female readers - in the tradition of Richardson, such as Pamela, Clarissa or Sidney Bidulph (Mudde 81) or, as a matter of fact, Poor Liza by Russian writer Nikolay Karamzin. Finally, the Dutch translations have no trace of the second, generic title "Novel in four parts and an epilogue," which Dostoevsky had given to the source text in 1879 (Roesen 151). 

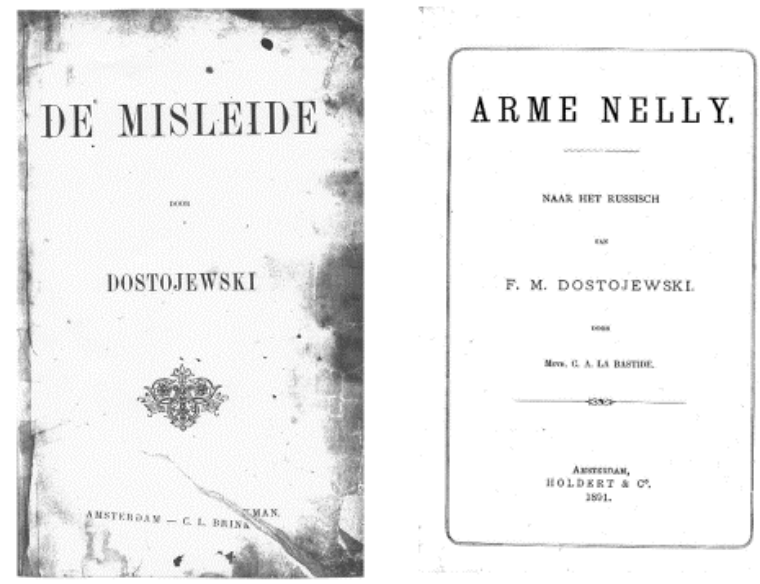

Figure 2: The titles pages of Arme Nelly and De misleide

Neither De misleide nor Arme Nelly have prefaces. However, the German intermediate text Erniedrigte und Beleidigte (Dostojewski 1885), upon which the former Dutch target text (De misleide) was largely based, does contain a preface, in which the German translator Konstantin Jürgens accounts for "Einige Kürzungen" [some shortenings] (5-6). In the case of De misleide, there is an even stronger indication that the dominant translation norm was acceptability. Shortly after its publication, the Dutch publisher C. L. Brinkman launched the following slightly contradictory but overall rather outspoken advertisement:

On several occasions, Dostoevsky was accused of roughness and vulgarity. In the work we present to the Dutch readership, not one touch of this can be detected, and when we did discover traces, we avoided the obstacle as much as possible. Therefore, we do not doubt that in this respect De misleide will also meet the requirements that a cultured readership demands, and rightly so, of any literary product. (191) my italics and translation from Dutch) 
Given the ample indications provided by their paratexts and epitexts, it comes as no surprise that both De misleide and Arme Nelly are marked by significant macrostructural shifts from the corresponding Russian source text. In the case of De misleide, the main macrostructural shifts were introduced by the German intermediate translator. Very much in line with the statement in his preface to Erniedrigte und Beleidigte (Dostojewski 1885), Jürgens omitted approximately 1,500 lines in total, which corresponds with roughly $11 \%$ of the Russian source text. These omissions were proportionally distributed so that the storylines were minimally affected. In turn, the anonymous Dutch translator clearly did not consider it necessary to omit even more: only three sentences of the German intermediate text are missing in the Dutch source text (Boulogne 2011, 508).

In sharp contrast to the Retranslation Hypothesis, Arme Nelly turns out - macrostructurally - to be an even more acceptabilityoriented translation than De misleide. Nearly $35 \%$ of the source text was omitted. In this case, the omissions were not initiated by the German intermediate translator (who had actually delivered a macrostructurally adequate text): they were introduced directly by the Dutch translator, C.A. La Bastide. Interestingly enough, she did not distribute the omissions proportionally: in addition to less significant omissions in various chapters, 13 chapters from the intermediate text were omitted in their entirety. It is striking that the chapters most targeted were those which put the spotlight on Alyosha, his father Valkovsky and his bride-to-be. To a lesser extent we find omissions in the sentimental storyline about Natasha and her unhappy love. As a result, just as its title suggests, the novel by Dostoevsky is mainly limited to the storyline that focuses on poor Nelly. These shifts make it impossible to shake the impression that La Bastide engrafted her translation strategy onto the criticism formulated by Vogüé. He had stated that the novel was too long and complex, that the characters Alyosha and Valkovsky were disturbing and that Nelly was delectable.

Although at macrostructural level the retranslation Arme Nelly is significantly less adequate than the preceding translation 
De misleide, this case study does not completely contradicts the Retranslation Hypothesis. As a matter of fact, Arme Nelly provides the reader with a slightly more adequate picture of Dostoevsky's anti-German satire than De misleide, which is partly due to translation strategies adopted by the German intermediate translators (Boulogne 2016, 122). At the same time, La Bastide's retranslation - to a higher degree than De misleide - is marked by a clear tendency towards naturalization and neutralization concerning the original couleur locale and heteroglossia (Boulogne 2012). In addition, La Bastide significantly softened Dostoevsky's mockery of Jesuits and some of his sexual allusions (Boulogne 2011, 695-696). Examples of strategic additions can be found in the text, which strengthen the sentimental dimension of the novel, quite in line with the metaliterary connotations of the work's new title. In the passage below, for instance, the Dutch translator added the italicized sentence "... and I was overwhelmed by an indescribable feeling of compassion with the poor little, young human being, who had endured already so much in her short little life" (my translation from Dutch).

Представилась мне и

Нелли, вспоминавшая всё это уже одна, без мамаши своей, когда Бубнова побоями и зверскою жестокостью хотела сломить ее и принудить на недоброе дело. (Dostoevskij 1972, 432)
Dann stellte ich mir Nelly vor, wie sie allein geblieben, als ihre Mama sie verlassen hatte, als die Bubnow sie mit Schlägen und Grausamkeit zum Bösen zwingen wollte. (Dostojewski 1890, 281)
Ik stelde mij Nelly voor, zooals zij geweest moest zijn, toen zij alleen was achtergebleven en juffrouw Bubnow haar door ruwe woorden en barbaarsche mishandelingen tot een leven van schande en ontucht wilde dwingen... en een onbeschrijfelijk gevoel van medelijden met het arme, jonge schepseltje, dat in haar korte leven reeds zooveel ondervonden had, greep mij aan. (my italics, Dostojewsky 1891, 172) 


\subsection{Two more early Dostoevsky retranslations into Dutch}

Apart from Arme Nelly, two more Dostoevsky retranslations were produced in the Netherlands before the outbreak of the First World War. Dostoevsky's novel Crime and Punishment, about a student who commits and confesses to the murder of an elderly pawnbroker, was retranslated in 1895 into Dutch in two parts, respectively entitled Een misdaad [A crime] and Wroeging [Remorse]. The very existence of this retranslation cannot be explained by referring to the Retranslation Hypothesis. The first Dutch translation of the same Russian source text, published in 1886 under the title Schuld en boete (Guilt and penance), has been analyzed as a macrostructurally relatively adequate translation (Boulogne 2011, 478-480). It was based on the German intermediate text Raskolnikow (Dostojewskij 1882). As shown in Figure 3, the Dutch retranslation Een misdaad/Wroeging was translated not from Russian or German, but from French: from the bestseller $L e$ crime et le châtiment (Dostoïevsky 1884). The very fact that the publisher and/or translator opted for a French intermediate text can be understood as recognition of the essential role that France had played in the popularization of Dostoevsky in Europe in general (Boulogne 2015) and in the Netherlands and in Flanders in particular (Boulogne 2013). Because Dostoevsky translations into French were generally marked by more significant macrostructural shifts from the corresponding source texts than Dostoevsky translations into German (Boulogne 2011, 548-550), the choice for French as an intermediate language can hardly be understood as an attempt to provide a higher degree of adequacy. The title of the Dutch translation alone speaks volumes about its lack of concern for adequacy: whereas the Russian word 'наказание' (punishment) is a legal term, the Dutch word "wroeging" (remorse) has a Christianmoral connotation. It clearly refers to Raskolnikov's presumed psychological state after the murder, although the epilogue of the Russian source text explicitly mentions that the young murderer, even after his conviction, feels no remorse. 
Prestuplenie

inakazanie (1866)

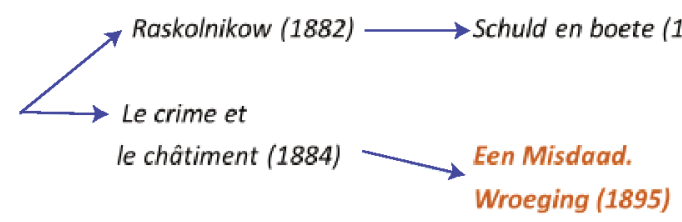

Figure 3: The Dutch retranslation Een misdaad. Wroeging (1895)

The last Dostoevsky retranslation into Dutch that appeared in the period under investigation here - ending with the First World War -, was Uit het Doodenhuis [From the dead house] (Dostojewski 1906), a translation from Notes from the House of the Dead. Fifteen years earlier, in 1891, Dostoevsky's fictionalized report of his own Siberian experience had been translated into Dutch under the title Uit Siberië [From Siberia] (see Figure 4). Whereas this target text was a case of eclectic indirect translation, based on French and German intermediate texts, the retranslation Uit het Doodenhuis was based on a single intermediate text, that is, the German text Aus dem todten Hause (Dostojewski 1890), which itself was also a retranslation. ${ }^{4}$ This choice was clearly not motivated by an increased concern for adequacy, as the Dutch retranslation is macrostructurally even less adequate with respect to the Russian source text than the previous Dutch translation. The reason for this decrease in macrostructural adequacy is that the chosen German intermediate text Aus dem todten Hause (Dostojewski 1890) is marked by numerous omissions when compared with the Russian source text. Such omissions are in line with the criticism of the time, widespread in both France and Germany, that Dostoevsky was too prolix a writer. At the same time, at microtextual level, the Dutch retranslation Uit het Doodenhuis

4 The first German translation of Notes from the House of Dead was also the very first translation of a book by Dostoevsky. It appeared already in 1864, when Dostoevsky was still unknown outside of Russia. However, because of its lack of commercial success, the publisher Wolfgang Gerhard was forced to sell the unsold copies as scrap paper (Zabel, 333).

Cad. Trad., Florianópolis, v. 39, $\mathbf{n}^{0}$ 1, p. 117-144, jan-abr, 2019. 
does present the Dutch reader with a slightly more adequate picture of Russian proper names (Boulogne 2011, 558) and of Dostoevsky's mockery of Germans (Boulogne 2016, 122) than the previous Dutch translation of the same source text.

Zopiski iz

Mërtwogo doma (1860-62)

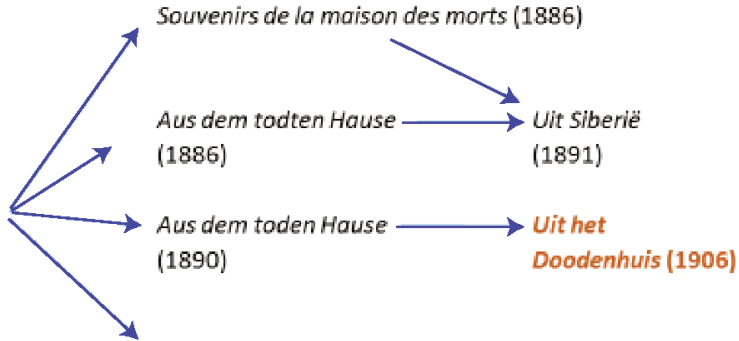

Aus dem toden Hause (1864)

Figure 4: The Dutch retranslation of Notes from the House of Dead

\section{Conclusions}

This historical survey has shed light on the three earliest Dostoevsky retranslations into Dutch and has provided an overview of the most recent Dostoevsky retranslations into Dutch that is deeper than the insights from popular assumptions. In addition, discussion about the recent Dostoevsky retranslations into Dutch can also enrich possible interpretations of the motivation behind the earliest retranslations. It is this historical bifocality that can prevent us from giving too much credit or weight to simply one explanation.

At first sight, the historical perspective supports the Retranslation Hypothesis: whereas the early Dostoevsky retranslations into Dutch were indirect and marked by spectacular macrostructural shifts from the Russian source texts, the discussion about the quality of the translations today is bound to more detailed elements of Dostoevsky's writing style. However, upon closer inspection, one 
observes that the historical analysis undermines the Retranslation Hypothesis in more than one respect.

First, it proves - not for the first time, as is clear from the survey article by Cecilia Alvstad and Alexandra Assis Rosa (15) - that retranslation can also occur when the first translation is still 'fresh': the very first Dostoevsky retranslation occurred with a delay of only five years vis-à-vis the preceding translation of the same source text. As Van Poucke points out:

The almost simultaneous appearance of translations of the same work may serve as a working example that changes in linguistic or translational conventions alone cannot sufficiently explain the swift appearance of new versions of a literary translation and that there have to be other process at work. (95)

Second, the three case studies strongly suggest that the Retranslation Hypothesis is too simplistic: the variety of choices made in the analyzed Dostoevsky retranslations make it difficult - if not impossible - to unambiguously answer the question of whether a given Dostoevsky retranslation is more adequate or less adequate than the previous translation of the same source text. Or, to use the words of Vanderschelden: "Quality in translation does not follow objective universal criteria, and those involved in literary translation have different priorities, let alone their own personal convictions on what constitutes a good literary translation" (6). In discussions about whether, for instance, the Dostoevsky retranslation of Devils by Boland is more adequate than the previous translation of the same source text, the answer largely depends on the focus of the criteria. It could be argued that in regard to what Werner Koller labels "the pragmatic equivalence" (also called communicative equivalence), at some points Boland's translation is indeed adequate, since it effectively reproduces Dostoevsky's oft-overlooked wit. 
Third, the observation that all three Dostoevsky retranslations into Dutch of the period at hand are - from a macro-level - less source-text-oriented than the preceding Dutch translations of the same Russian source texts proves the point - already made by Sharon Deane-Cox and numerous other translation scholars - that the Retranslation Hypothesis has no general predictive value.

The macrostructural shifts that mark the early Dostoevsky retranslations into Dutch remind us of the importance of the insight, discussed in detail by Itamar Even-Zohar, that translation norms differ according to the position that is foreseen for the translated works within the receiving polysystem. If one takes into account that not every author gains increasingly more prestige over time and that even generalized processes of literary decanonization can take place (Mihaila 27), this insight fundamentally contradicts the Retranslation Hypothesis. In the case of Dostoevsky, the observed shifts seem to demonstrate how his early Dutch translators felt an ever-growing need to make his works - which were less successful in the Netherlands and Flanders than in France or Germany - more acceptable for the Dutch literary market. This can be tentatively explained by the hypothesis that the author's Dutch prestige had been overestimated by his first Dutch translators.

On the basis of historical analysis, it seems that the concept of norms, as conceived by Gideon Toury, is a better tool than the Retranslation Hypothesis to interpret and to explain the phenomenon of the Dostoevsky retranslations into Dutch. Cecilia Alvstad and Alexandra Assis Rosa mention that most authors explain retranslation by referring to "a different historical, cultural and ideological context and evolving linguistic, textual, literary and translational norms" (15, my italics). In the specific case of Dostoevsky, it seems that, in a first stage, the change of norms leading to his retranslation was provoked by a reevaluation of his prestige, whereas in most recent years, it was provoked by a change in linguistic norms, by different working conditions and by an increased appreciation of Dostoevsky's polyphonic writing style. 
However, as carefully highlighted by Siobhan Brownlie (155), translation norms and other verbal norms cannot exhaustively explain retranslation. First, it has become clear that retranslations of prestigious classical authors such as Dostoevsky can also be motivated, independently of a change in norms, by publishers' and/ or translators' desires to gain financial and/or symbolical capital. The commercial and critical success of the recent Dostoevsky retranslations prove the point made by Otto Boele (par. 23) that retranslation of classical writers, who generally sell (relatively) well and whose copyright has expired, tends to be more profitable than translations of recent Russian writers who are locally still unknown. In addition, the study of the early and recent Dostoevsky retranslations reminds us of the complexity of norms, many of which are not explicitly formulated. It seems safe to say that just like translation itself, retranslation is also a guessing game that forces the translator time and again to choose between continuously varying and sometimes contradicting norms. Take, for instance, Dostoevsky's mockery of Jews in Devils (more widely known as The Possessed): on the one hand, given the author's canonical status, a translator may feel forced to translate such mockery adequately. On the other hand, given the tradition of political correctness, a translator may feel compelled to somehow soften such mockery. The final main reason why norms cannot fully explain retranslation is of a more existential nature: the fuss about the recent Dostoevsky translation by the renowned Dutch translator Hans Boland - more precisely his polemical use of anachronisms -, illustrates that translators, especially when they are wellestablished, can also choose to violate given norms. Ironically, it is precisely the existence of this 'free will,' this refusal of humankind to be subjected to the laws of nature or society, that was one of the key points that Dostoevsky tried to illustrate in many of his novels. 


\section{References}

Abrahams, Roger. "De vertalers: 'Dostojevski is mijn core business'." Roger Abrahams. Taal \& Geschiedenis, rogerabrahams.nl/vertalers-dostojevski-is-corebusiness/. Accessed 31 Mar. 2018.

Alvstad, Cecilia and Alexandra Assis Rosa. "Voice in retranslation. An overview and some trends." Target. International Journal of Translation Studies, vol. 27, no. 1, 2015, pp. 3-24.

Bakhtin, M.M. Problems of Dostoevsky's Poetics, edited by Caryl Emerson, University of Minnesota Press, 1984.

Berman, Antoine. "La retraduction comme espace de la traduction." Retraduire, edited by Paul Bensimon and Didier Coupaye, Publications de la Sorbonne Nouvelle, 1990, pp. 1-7.

Boele, Otto. "Slozhnye prodazhi: russkaia literatura v Gollandii." Oktiabr', no. 10, 2006, magazines.russ.ru/october/2006/10/bu9.html. Accessed 31 Mar. 2018.

Boland, Hans. Zeer Russisch zeer. Over Dostojevski's Duivels. Triade, 2008.

. "Vertalersprobleem: de abominabele schrijfstijl van een groot schrijver." Filter. Tijdschrift over vertalen, vol. 23, no. 2, 2016, pp. 23-28, www.tijdschriftfilter.nl/jaargangen/2016/232/ vertalersprobleem-de-abominabele-schrijfstijl-vaneen-groot-schrijver-23-28.aspx. Accessed 31 Mar. 2018.

. "Polemiek: abominabele schrijfstijl. Reactie op de column van Willem Weststeijn." Filter. Tijdschrift over vertalen, 6 februari 2017, www.tijdschriftfilter.nl/webfilter/actueel/2017/week-6/polemiek-\%E2\%80\%98abominabeleschrijfstij1\%E2\%80\%99.aspx. Accessed 31 Mar. 2018.

Boulogne, Pieter. Het temmen van de Scyth. De vroege Nederlandse receptie van F.M. Dostoevskij. Pegasus, 2011. 
. "Vers la construction d'un Dostoïevski monophonique: Hétéroglossies et langage écorché dans les traductions néerlandaises d'avant-guerre des oeuvres de Dostoïevski." Canadian Review of Comparative Literature, vol. 39, no. 1, 2012, pp. 48-63.

. "De Rus uit Parijs. Dostojevski en de grenzen van de Nederlandse en Vlaamse literatu(u)r(en)." De Negentiende Eeuw. Tijdschrift van de Werkgroep De Negentiende Eeuw. Themanummer Het Frans als lingua franca: gevallen van histoire croisée in de Lage Landen, 1800-1914, vol. 37, no. 3, 2013, pp. 201-216.

. "Europe's Conquest of the Russian Novel. The Pivotal role of France and Germany." IberoSlavica, A Peer-Reviewed Yearbook of the International Society for Iberian-Slavonic Studies. Special Issue: Translation in Iberian-Slavonic Exchange, edited by Hanna Pięta and Theresa Seruya, 2015, pp. 167-191.

. "Champion of the Humiliated and Insulted or Xenophobe Satirist? Dostoevsky's Mockery of Germans in early translation." Interconnecting Translation and Imagology, edited by Luc Van Doorslaer et al., John Benjamins, 2016, pp. 109-125.

Brinkman, C.L. "De misleide door Dostojewski." Een liefde. Tweede deel, by L. van Deyssel, Brinkman, 1887, pp. 191-192.

Brownlie, Siobhan. "Narrative Theory and Retranslation Theory." Across Languages and Cultures, vol. 7, no. 2, 2006, pp.145-170.

Collombat, Isabelle. "Le XXI" siècle : l'âge de le retraduction. The $21^{\text {st }}$ Century: the Age of Retranslation." Translation Studies in the New Millenium An international Journal of Translation and Interpreting, vol. 2, 2004, pp. 1-15.

Deane-Cox Sharon. Retranslation: Translation, Literature and Reinterpretation. Bloomsbury, 2014.

Dostoevskij, F.M. Polnoe sobranie sočinenij v tridcati tomach. Chudožestvennye proizvedenija. Tom IV. Zapiski iz mërtvogo doma. Nauka, 1972.

Dostoievsky, F. Een misdaad. Russische roman. Amsterdam, Het Volksdagblad, 1895. 
.Wroeging. Russische roman. Amsterdam, Het Volksdagblad, 1895.

Dostoïevsky, Th. Le crime et le châtiment. Paris, Plon, 1884.

. Les humiliés et offensés. Paris, Plon, 1884.

. Souvenirs de la maison des morts. Paris, Plon. 1886.

Dostojefsky, F.M. Uit Siberië. Amsterdam, S. Warendorf Jr., 1891.

Dostojewski. De misleide. Amsterdam, C.L. Brinkman, 1886.

Dostojewski, F.M. Erniedrigte und Beleidigte. Berlin, Otto Janke, 1890.

. Aus dem todten Hause. Berlin, Otto Janke, 1890.

. Uit het Doodenhuis. Amsterdam, Cohen Zonen, 1906.

Dostojewski, Theodor. Erniedrigte und Beleidigte. Roman. Berlin-Stuttgart, Verlag von W. Spemann, 1885.

. Aus dem todten Hause. Denkwürdigkeiten eines nach Sibirien Verbannten.

Dresden-Leipzig, Verlag von Heinrich Minden, 1886.

Dostojewskij, F.M. Raskolnikow. Leipzig, Friedrich, 1882.

Dostojewsky F.M. Arme Nelly. Amsterdam, Holdert, 1891.

Even-Zohar, Itamar. "The Position of Translated Literature within the Literary Polysystem." New Perspectives in Literary Studies with a basic Bibliography of books on Translation Studies, edited by James S. Holmes et al., Acco, 1978, pp. 117-127. 
Frank, Joseph. Dostoevsky. The Stir of Liberation. 1860-1865. Princeton University Press, 1986.

Heijne, Bas. "Nederlandse vertaler weigert hoogste onderscheiding om Poetin." $N R C$, 6 september 2014, www.nrc.nl/nieuws/2014/09/06/nederlandse-vertalerweigert-hoogste-onderscheiding-om-poetin-a1422600, Accessed 31 Mar. 2018.

Jürgens, Konstantin. "Einleitung”. Erniedrigte und Beleidigte. Roman, by Theodor Dostojewski, Berlin-Stuttgart, Verlag von W. Spemann, 1885, pp. 5-6.

Koller, Werner. Einführung in die Übersetzungswissenschaft. Quelle \& Meyer, 1979.

Langeveld, Arthur. "Nawoord bij de vertaling." Verzamelde werken. De broers Karamazov, by F. M. Dostojevski, G.A. van Oorschot, 2006, pp. 961-962.

Metz, Eric. "Apologetische en polemische tendensen van de hervertaling: Poesjkin en de paratekst van Hans Boland." Filter. Tijdschrift over vertalen, vol. 21, no. 3, 2014, pp. 20-24.

Mihaila, Rodica. "Envisioning the future of the American feminist literary (counter)canon." Journal of Research in Gender Studies, vol 1, no. 2, 2011, pp. 24-32.

Mudde, Brenda. Richardsons apostel in Nederland. Johannes Stinstra als vertaler en pleitbezorger van Samuel Richardsons Clarissa (unpublished thesis). Universiteit Utrecht, 2007.

Paloposki, Outi \& Koskinen, Kaisa. "Thousand and One Translations: Retranslation Revisited." Claims, Changes, and Challenges, edited by Gyde Hansen et al., John Benjamins, 2004, pp. 27-38.

Reinholdt, Alexander von. "F.M. Dostojewski. 1821-1881." Baltische Monatschrift, vol. 29, no. 4, 1882, pp. 253-276.

Roesen, Tine. "Dostoevskij's genres - Towards a differentiation." Perspectives on Slavic Literatures. Proceedings of the First International "Perspectives on 
Slavistics" Conference, edited by David S. Danaher and Kris Van Heuckelom, Pegasus, 2007, pp. 141-160.

Skibińska, Elżbieta. "Retranslation: Literature and Reinterpretation" Translation Studies, vol. 9, no. 2, 2015, pp. 236-239.

Steenmeijer, Maarten. "Márquez brengt zelfs zijn vertaler in verwarring" Volkskrant, 20 mei 2017, www.volkskrant.nl/boeken/gabriel-garcia-marquezbrengt-zelfs-zijn-vertaler-in-verwarring a4495848/. Accessed 31 Mar. 2018.

Toury, Gideon. Descriptive Translation Studies and Beyond. John Benjamins, 1995.

Unesco. "Index Translationum - "TOP 50" Author." Index Translationum, www. unesco.org/xtrans/bsstatexp.aspx?crit $1 \mathrm{~L}=5 \& \mathrm{nTyp}=\min \&$ topN $=50 . \quad$ Accessed 31 Mar. 2018.

Vanderschelden, Isabelle. "Why Retranslate the French Classics? The Impact of Retranslation on Quality." On translating French literature and film. II, edited by Myriam Salama-Carr, Rodopi, 2000, pp. 1-18.

Van Poucke, Piet. "Aging as a motive for literary translation. A survey of case studies on retranslation" Translation and Interpreting Studies, vol. 12, no. 1, 2017, pp. 91-115.

Venuti, Lawrence. The Translator's Invisibility: A History of Translation. Routlegde, 2015.

Vogüé, Eugène Melchior de. "Les écrivains russes contemporains." Revue des deux mondes, vol. 67, 1885, pp. 312-356.

. Le roman russe. Paris, Plon, 1886.

. "Avertissement." Souvenirs de la maison des morts, by Th. Dostoïevsky, Paris, Plon, 1886, pp. i-xvi. 
Waegemans, Emmanuel.. Bibliografie van Russische literatuur in Nederlandse vertaling. 1789-1985. Universitaire Pers Leuven, 1991.

. Bibliografie van Russische literatuur in Nederlandse vertaling. 19852015. Benerus, 2016.

Weststeijn, Willem G. "Boze geesten, duivels en demonen." Filter. Tijdschrift over vertalen, vol. 16, no. 4, 2009, pp. 40-48, www.tijdschrift-filter.nl/ jaargangen /2009/164/boze-geesten,-duivels-en-demonen-40-48.aspx. Accessed 31 Mar. 2018.

. "Een groot schrijver met een abominabele schrijfstij1?" Filter. Tijdschrift over vertalen, 2017 week 5, tijdschrift-filter.nl/webfilter/vrijdag-vertaaldag/2017/ week-5-willem-weststeijn.aspx. Accessed 31 Mar. 2018.

Zabel, Eugen. "Porträts aus dem russischen Literaturleben." Unsere Zeit. Deutsche Revue der Gegenwart. Neue Folge, vol. 19, 1884, pp. 332-346.

Recebido em: 12/08/2018

Aceito em: 12/11/2018

Publicado em janeiro de 2019

Pieter Boulogne. E-mail: pieter.boulogne@kuleuven.be ORCID: https://orcid.org/0000-0001-7516-688X 